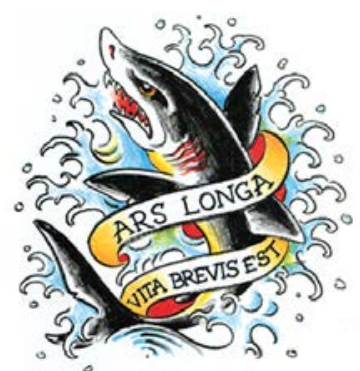

SHARK'S INK. 550 BLUE MOUNTAIN ROAD LYONS CO 805403038239190 WWW.SHARKSINK.COM PRINTSHARK@GMAIL.COM

\title{
JANE HAMMOND
}

BIRTH: $\quad 1950$

Bridgeport, Connecticut

EDUCATION: $\quad$ B.A. $\quad \begin{aligned} & \text { Mount Holyoke College } \\ & \text { South Hadley, Massachusets }\end{aligned}$

1972

Arizona State University

$1973-4$

Tempe, Arizona

M.F.A. University of Wisconsin--Madison 1977

Madison, Wisconsin

\section{SELECTED PUBLIC COLLECTIONS:}

Addison Gallery of American Art, Andover, MA

Albertina, Vienna, Austria

Albright-Knox Art Gallery, Buffalo

Aldrich Museum of Contemporary Art, Ridgefield, CT

Amon Carter Museum of American Art, Fort Worth, TX

Arkansas Arts Center, Little Rock, AR

Art Institute of Chicago

Baltimore Museum of Art

Biblioteque Nationale, Paris, France

Brooklyn Museum of Art

Chazen Museum of Art, University of Wisconsin, Madison

Cincinnati Art Museum

The Colorado Collection, University of Colorado at Boulder, CO

The Contemporary Art Museum St. Louis

The Corcoran Gallery of Art, Washington, DC

The Detroit Institute of Arts

The deYoung Museum, San Francisco, CA

The Fogg Art Museum, Harvard University

Fort Wayne Musuem of Art, Ft. Wayne, IN

Grand Valley State University, Grand Rapids, MI

Grunewald Center for Graphic Arts, Los Angeles, CA

Herbert F. Johnson Museum, Cornell University, Ithaca, NY

Honolulu Academy of Art, Honolulu, HI

Hood Museum of Art, Dartmouth College, Hanover, NH

Joslyn Art Museum, Omaha, NB

The Library of Congress

Maryland Institute College of Art, Baltimore, MD

Madison Museum of Contemporary Art, Madison, WI

Museo de Arte Contemporaneo, Mexico City, Mexico

Metropolitan Museum of Art

Milwaukee Art Museum

Mount Holyoke College Art Museum 
Museum of Contemporary Art, Chicago

Museum of Contemporary Art San Diego

Museum of Fine Arts, Boston

Museum of Modern Art, New York City

National Gallery of Art, Washington, DC

National Museum of Women in the Arts, Washington, DC

New York Public Library

Orlando Museum of Art, Orlando, FL

Portland Art Museum, Portland, OR

Princeton University Art Museum, Princeton, NJ

Saint Louis Art Museum

San Francisco Museum of Modern Art

San Jose Museum of Art

Seattle Art Museum, Seattle, WA

Smith College Museum of Art, Northampton, MA

Smithsonian American Art Museum, Washington, DC

Spencer Museum of Art, University of Kansas, Lawrence, KS

Toledo Museum of Art, $\mathrm{OH}$

Tucson Museum of Art, AZ

The Walker Art Center

Weatherspoon Art Museum, The University of North Carolina, Greensboro

Wellesley College Davis Museum and Cultural Center, Wellesley, MA

The Whitney Museum of American Art

Yale University Art Museum

ONE PERSON EXHIBITIONS:

2012

2011

2010

2009

2008

2007 $5^{\text {th }}$ Beijing International Art Biennale

"Light Now: Dazzle Paintings and Photographs," Galerie Lelong, New York, NY

"Jane Hammond: Fallen,” FLAG Art Foundation, New York, NY

"Cabinet de Curiosites," Galerie Lelong, Paris, France

"Jane Hammond: New Collaged Monoprints," Pace Prints, New York, NY

"Fallen,” Taubman Museum of Art, Roanoke, VA

"Jane Hammond: Photographs,” Museum of Contemporary Art, Denver, CO

Galeria Senda, Barcelona, Spain

"Fallen,” Museum of Contemporary Art San Diego, CA

Jane Hammond: New Photographs of Late," Visual Arts Gallery, University of Alabama, Birmingham, AL

"Jane Hammond," Brevard Art Museum, Melbourne, FL

"Internally Displaced: Jane Hammond and Enrique Chagoya," A + D Gallery, Columbia College, Chicago, IL

"Photographs," Galerie Lelong, New York, NY

"People, Places and Things,” Lemberg Gallery, Ferndale, MI

Jane Hammond: Paper Work," traveling to Herbert F. Johnson Museum, Cornell

University, Ithaca, NY; the Achenbach Foundation at the DeYoung Museum, San Francisco, CA; and the Detroit Institute of Arts, Detroit, MI (with catalogue)

"Fallen,” Wexner Center for the Arts, Columbus, $\mathrm{OH}$

“Jane Hammond: Photographs,” Museum of Contemporary Art, Denver, CO

"Jane Hammond: Paper Work,” traveling to Tucson Museum of Art, Tucson, AZ; Chazen Musuem of Art, University of Wisconsin, Madison, WI; and the Arkansas Arts Center, Little Rock, AR; (with catalogue)

McNay Art Museum, San Antonio, Texas

Greg Kucera Gallery, Seattle, Washington 
“Jane Hammond: Paper Work,” Mt. Holyoke College Museum of Art, South Hadley, MA, traveling to Tucson Museum of Art, Tucson, AZ; Chazen Musuem of Art, University of Wisconsin, Madison, WI; Arkansas Arts Center, Little Rock, AR; Herbert F. Johnson Museum, Cornell University, Ithaca, NY; the Achenbach Foundation at the DeYoung Museum, San Francisco, CA; and the Detroit Institute of Arts, Detroit, MI (with catalogue)

“Jane Hammond: Monoprints," Pace Prints, New York, NY

Galeria Senda, Barcelona, Spain (with catalogue)

"Recent Photographs”, Jaffe-Friede and Strauss Galleries, Hopkins Center, Dartmouth College, Hanover, New Hampshire (with catalogue)

Galeria Vanguardia, Bilbao, Spain

William Shearburn Gallery, St. Louis, MO

Nina Freudenheim Gallery, Buffalo, New York

2005 Galerie Lelong, New York, New York

Wetterling Gallery, Stockholm, Sweden (with catalogue)

Byron Cohen Gallery, Kansas City, Missouri

Greg Kucera Gallery, Seattle, Washington

Weatherspoon Art Museum, The University of North Carolina, Greensboro, North Carolina (with catalogue)

"Be Zany, Poised Harpists; Be Blue, Little Sparrows,” San Francisco Public Library, Book Arts and Special Collections, San Francisco, California

John Berggruen Gallery, San Francisco, California

Galeria Vanguardia, Bilbao, Spain

Lemberg Gallery, Ferndale, Michigan

David Floria Gallery, Aspen, Colorado

2002 Whitney Museum of American Art at Philip Morris, New York, New York (brochure)

"Be Zany, Poised Harpists; Be Blue, Little Sparrows," Dieu Donné Gallery, New York, New York (brochure)

Galeria Senda, Barcelona, Spain

$2001 \quad$ Galerie Lelong, New York, New York

Cleveland Center for Contemporary Art, Cleveland, Ohio (with catalogue), traveling to The Contemporary Museum, Honolulu, Hawaii; Madison Art Center, Madison, Wisconsin; and Blaffer Gallery, The Art Museum of the University of Houston, Texas

Lemberg Gallery, Ferndale, Michigan

Greg Kucera Gallery, Seattle, Washington

1999 Lemberg Gallery, Birmingham, Michigan

Galeria Senda, Barcelona, Spain

"Jane Hammond and Judy Pfaff," Byron Cohen Gallery, Kansas City, Missouri

David Beitzel Gallery, New York, New York

Zolla/Lieberman Gallery, Chicago, Illinois

David Floria Gallery, Aspen, Colorado

Galerie Barbara Farber/Rob Jurka, Amsterdam, The Netherlands

1997 Luhring Augustine, New York, New York

Greg Kucera, Seattle, Washington

West Virginia University, Morgantown, West Virginia

1996 Lemberg Gallery, Birmingham, Michigan

Galerie Barbara Farber, Amsterdam, The Netherlands 
The Orlando Museum of Art, Orlando, Florida, traveling to The Freedman Gallery, Albright College, Reading, Pennsylvania (with brochure)

Jose Freire Fine Art, New York, New York (In collaboration with John Ashbery) (with catalogue)

1993 Cincinnati Museum of Art, Cincinnati, Ohio (with brochure)

Greg Kucera Gallery, Seattle, Washington

Feigenson-Preston Gallery, Birmingham, Michigan

1992 Transepoca Gallery, Milan, Italy

Heland Wetterling Gallery, Stockholm, Sweden

1991 fiction/non-fiction, New York, New York

Feigenson-Preston Gallery, Birmingham, Michigan

1990 Gallery Wetterling, Goteborg, Sweden (with catalogue)

Zolla/Lieberman Gallery, Chicago, Illinois

Honolulu Academy of Art, Honolulu, Hawaii (with brochure)

fiction/non-fiction Gallery, New York, New York

1989 Exit Art, New York, New York (with catalogue)

1987 Nina Freudenheim Gallery, Buffalo, New York

\section{GROUP EXHIBITIONS:}

2012 Houdini: Art and Magic,” Contemporary Jewish Museum, San Francisco, CA and Madison Museum of Contemporary Art, Madison, WI

"Struggle(s)," Maison Particuliere Art Center, Brussels, Belgium

"Art=Text=Art: Works by Contemporary Artists,” Jane Vorhees Zimmerli Art Museum, Rutgers University, New Brunswick, NJ

“[Re] Current: 50 Years of Prints," Greg Kucera Gallery, Seattle, WA

"The Human Touch: Selections from the RBC Wealth Management Art Collection," The Blanton Museum of Art, Austin, TX

"Currents in Contemporary Art,” Orlando Museum of Art, Orlando, FL

"Printmaking Today," Cincinnati Art Museum, Cincinnati, $\mathrm{OH}$

"Renegade Humor," San Jose Museum of Art, San Jose, CA

"Every Exit is An Entrance: 30 Years of Exit Art,” Exit Art, New York, NY

"Multiplicity," Smithsonian American Museum of Art, Washington, DC

"Prints Please: Selections for Universal Limited Art Editions," Islip Art Museum, East Islip, NY

"Gift of a Lifetime: The James Pearson Duffy Collection," Detroit Institute of Arts, Detroit, MI

"Bling," Jim Kempner Fine Art, New York, NY

"Ripped: The Allure of Collage," The Heckscher Museum of Art, Huntington, NY

2011 "Houdini: Art and Magic,” Skirball Cultural Center, Los Angeles, CA traveling to Contemporary Jewish Museum, San Francisco, CA and Madison Museum of Contemporary Art, Madison, WI

"Multiplicity," Smithsonian American Museum of Art, Washington, DC

"Gift of a Lifetime: The James Pearson Duffy Collection," Detroit Institute of Arts, Detroit, MI

"Ripped: The Allure of Collage,” The Heckscher Museum of Art, Huntington, NY

"Forty for 40," Lemberg Gallery, Ferndale, MI

"Mars vs Venus: Images of Male and Female," Greg Kucera Gallery, Seattle, WA 
"Interventions in the Landscape," Galerie Lelong, New York, NY

“Olor, Color, Quimica, Art I Pedagogia,” Arts Santa Monica Museum, Barcelona, Spain

"Remix,” Lemberg Gallery, Ferndale, MI

"Art=Text=Art: Works by Contemporary Artists," Harnett Museum of Art, University of Richmond Museums, Richmond, VA

“Au Plasir du Livre,” Librairie Auguste Blaizot, Paris France

"It's a Zoo in Here! Prints and Drawings of Animals," Detroit Institute of Arts, Detroit, MI

"New and Noteworthy: Recent Acquisitions of Modern and Contemporary Art,” Joslyn Art Museum, Omaha, NB

"Feast," Lemberg Gallery, Ferndale, MI

"Cinematic Bodies," Zolla/Lieberman Gallery, Chicago, IL

"Paper A-Z," Sue Scott Gallery, New York, NY

"cartoGRAPHIC,” Larissa Goldston Gallery, New York, NY

“A Printer’s Spotlight: Fifteen Years of Wildwood Press,” Gallery 210, University of Missouri, St. Louis, MO

"American Printmaking Now," Zhejiang Art Museum, China traveling to Shanghai Art Museum, China

“Time Wounds All Heels,” White Flag Projects, St. Louis, MO

"Identity Crisis: Authenticity, Attribution and Appropriation,” Heckscher Museum of Art, Huntington, NY

2010 "Houdini: Art and Magic,” The Jewish Museum, New York, NY Exhibition to travel

“American Printmaking Now," National Art Museum of China, Beijing, China traveling to Guan Shanyue Art Museum, China

"The Fifth Genre: Considering the Contemporary Still Life,” Galerie Lelong, New York, NY

“30 Ans d'art contemporain a Roland Garros,” Musee de la Federation Francaise de Tennis, Paris, France

'The Grenfell Press: Thirty Years of Collaboration,” Knoedler Project Space, New York, NY

“Thirty-Fifth Anniversary Program,” Point of Contact Gallery, Syracuse, NY

"You Are Here," Pratt Manhattan Gallery, New York, NY

"The Legend of Bud Shark and His Indelible Ink," Loveland Museum Gallery, Loveland, CO

"Resurrectine," Ronald Feldman Fine Arts, New York, NY

“The Visible Vagina,” Francis M. Naumann Fine Art, New York, NY

"The Visible Vagina," David Nolan Gallery, New York, NY

"Shark’s Ink," Creative Arts Center, Wright State University, Dayton, OH

"Paper CUT, "Lemberg Gallery, Ferndale, MI

"Made in U.S.A.” Greg Kucera Gallery, Seattle, WA

2009 "Drawings and Prints: Selections from the Permanent Collection," Metropolitan Museum of Art, New York, NY

"Modern and Contemporary Art at Dartmouth: Highlights from the Hood Museum of Art," Hood Museum of Art, Hanover, NH

“Eye World,” Triple Candie, New York, NY

“Telling Secrets: Codes, Captions, and Conundrums in Contemporary Art,” The National Museum of Women in the Arts, Washington, DC

"The Legend of Bud Shark and His Indelible Ink," Museum of Contemporary Art/Denver, CO

"Robert Rauschenberg and His Contemporaries: Recent Prints from Universal Limited Art Editions," Heckscher Museum of Art, Huntington, NY

“I.D.: Individual Demographics,” Greg Kucera Gallery, Seattle, WA

“Jump Cut Pop,” Haggerty Museum of Art, Marquette University, Milwaukee, WI

"The Human Touch: Selections from the RBC Wealth Management Art Collection,” Yakima Valley Museum, Yakima, WA

“Talk Dirty to Me," Larisssa Goldston Gallery, New York, NY

“On Paper,” William Shearburn Gallery, Sante Fe, NM

“Good News,” Porter Butts Gallery, University of Wisconsin, Madison, WI

"Collaborative Vision: The Poetic Dialogue Project," Chicago Cultural Center, Yates Gallery, Chicago, IL traveling to Indiana State University Art Gallery, Terre Haute, IN and Bowling Green State University Art Gallery, Bowling Green, OH 
"Wunderkammer: A Century of Curiosities,” Museum of Modern Art, New York, NY

"Contemporary Prints and Drawings," Herbert F. Johnson Museum of Art, Cornell University, Ithaca, N.Y.

“30 ${ }^{\text {th }}$ Anniversary Group Show,” Wetterling Gallery, Stockholm, Sweden

" $25^{\text {th }}$ Anniversary Group Exhibition," Greg Kucera Gallery, Seattle, WA

"Envisioning Maps,” Hebrew Union College, Jewish Institute of Religion Museum, NY, NY

"A Pace Menagerie," Pace Prints Gallery, New York, NY

"Photographic Works, " Cohan and Leslie Gallery, New York, NY

"Shark's Ink. Revisited," Foster Gallery, University of Wisconsin, Eau Claire, WI

"INprint," SCA Contemporary Art, Albuquerque, NM

"Places," Jim Kempner Fine Art, New York, NY

"What is a Print?” Carl Solway Gallery, Cincinnati, OH

"The Body is Art," Michele Mosko Fine Art, Denver, CO

"On the Margins," Mildred Lane Kemper Art Museum, St. Louis, MO

“Collector's Choice III: Audacity in Art,” Orlando Museum of Art, Orlando, FL

2007 "Two Years," Whitney Museum of American Art, New York, NY

"Addicted to Paper," Galerie Lelong, Zurich, Switzerland

"Photography and the Self: The Legacy of F. Holland Day," Whitney Museum of American Art, NY

"American Art at Dartmouth: Highlights from the Hood Museum of Art," Dartmouth College, Hanover, $\mathrm{NH}$

"Lines in the Earth: Maps, Power and the Imagination,” Sun Valley Center for the Arts, Ketchum, ID

“What F Word?” Cynthia Broan Gallery, New York, NY

"Fresh," Gallery Eighty, Singapore

"Small Work,” Nina Freudenheim Gallery, Buffalo, NY

"Fresh,” Lemberg Gallery, Ferndale, MI

"Stories and Histories," Faulconer Gallery, Grinnell College, Grinnell, IA

“Making a Mark: Four Contemporary Artists in Print,” Yale University Art Gallery, New Haven, CT

“Out of Line: Drawings from the Collection of Sherry and Joel Mallin,” Herbert F. Johnson Museum, Cornell University, Ithaca, NY

“The Word as Image,” National Museum of Women in the Arts, Washington, DC

"Summer Selections," John Berggruen Gallery, San Francisco, CA

"The Message is the Medium," Jim Kempner Fine Art, New York, NY

"Gimme Shelter," 10a Serpentine Drive, Shelter Island Heights, Shelter Island, New York

"Summer Group Show,” Lemberg Gallery, Ferndale, MI

"Patchwork: Affinities and Influences in Contemporary Art," Greg Kucera Gallery, Seattle, WA

"Women in the Bedroom," Larissa Goldston Gallery, New York, NY

“New Prints 2006/Winter,” International Print Center, New York, NY

"Biella Print Triennale,” Museo del Territorio, Biella, Italy

"Super Bowl," Detroit Institute of Arts, Detroit, MI

"Remarkable Women," Peltz Gallery, Milwaukee, WI

"Paperwork: Books and Paper Collaborations by Sue Gosin and Dieu Donne Papermill and Press," Memorial Library, University of Wisconsin, Madison, WI

"3D: An Exhibition of Contemporary Sculpture," Carl Solway Gallery, Cincinnati, OH

2005 “Imagined Worlds: Willful Invention and the Printed Image 1470-2005,” Axa Gallery, New York, NY (with catalogue)

"Points of View: Landscape and Photography," Galerie Lelong, New York, NY

"Summer Group Show," Lemberg Gallery, Ferndale, MI

"Steven Scott Collects: Donations and Promised Gifts to the Permanent Collection,” National Museum of Women in the Arts, Washington, DC

“25 Ans D’art Contemporain,” Tenniseum: Le Musee de Roland-Garros, Paris, France

“Portraits on Paper,” Larissa Goldston Gallery, New York, NY 
"Five Presses: Selected Works,” Arvada Center for the Arts and Humanities, Arvada, CO

“Toy/Box” John Berggruen Gallery, San Francisco, CA

“Livres d'artistes americains en Europe, 1960-2000,” Musee d'Art Americain Giverny, Giverny, France

“New Prints 2004/Summer,” International Print Center, New York, NY

"What's That?" Children's Museum of Manhattan, New York, NY

"The Exit Art Print Show," Exit Art, New York, NY

"The Flag Project," Rubin Museum of Art, New York, NY

“The Sporting Women: The Female Athlete in American Culture,” Mount Holyoke College Museum of Art, South Hadley, MA

'Four Decades of Printmaking 1960 -2000: Selections from the Maslow Collection”, Everhart Musuem, Scranton, PA

“Constructing Realities, Part 2,” Selby Gallery, Ringling School of Art and Design, Sarasota, FL

“Toys "R” Art,” Galeria Senda, Barcelona, Spain

“Ten,” Byron Cohen Gallery, Kansas City, MO

"The Buddha Project," Cleveland State University Art Gallery, Cleveland, OH

"Art, Artists, and the Addison," Addison Gallery of American Art, Andover, MA

"ULAE: The Print Show,” Oklahoma City Museum of Art, Oklahoma City, OK

"Arte Termita Contra Elefante Blanco,” Museo ICO, Madrid, Spain (with catalogue)

"Super-Sized: The Big Print Show," Greg Kucera Gallery, Seattle, WA

“Roberta Lieberman, A Sharp Eye: An Art Dealer's 40 Year Journey,” Evanston Art Center, Evanston, IL

“ULAE: New Editions,” Art on Paper, Philadelphia, PA

2003 “Divergent,” Galerie Lelong, New York, NY

"I Love New York," Mary Ryan Gallery, New York, NY

"Color, Form, Figure” John Berggruen Gallery, San Francisco, CA

"Splendid Pages: The Molly and Walter Bareiss Collection of Modern Illustrated Books," Toledo Musuem of Art, Toledo, OH

"A Way With Words," John Berggruen Gallery, San Francisco, CA

"Art a Century Apart: 1903 and 2003," Mississippi Museum of Art, Jackson, MS

"On Paper: Masterworks from the Addison Collection," Addison Gallery of American Art, Andover, MA

"Contemporary Prints and Photographs from the Bruce Brown Collection," Colby College Museum of Art, Waterville, ME

"ULAE: Recent Editions," David Floria Gallery, Aspen, CO

"Word/Image,” Westport Arts Center, Westport, CO

"ULAE: New Editions,” Lemberg Gallery, Birmingham, MI

$2002 \quad$ "177 1 Annual," National Academy of Design, New York, NY.

"American Painting," Christian Dam Gallery, Oslo, Norway

"Universal Limited Art Editions," Devin Borden Hiram Butler Gallery, Houston, TX

"New York New Work Now!" Currier Museum of Art, Manchester, NH

"Resisting Catagories", The Gallery of South Orange, South Orange, NJ

"The Art of Healing II" Greg Kucera Gallery, Seattle, WA

"One Thousand Words: Storytelling Images from Cultures Around the World,” John Michael Kohler Arts Center, Sheboygan, WI

'Remarkable Women," Peltz Gallery, Milwaukee, WI

2001 "Digital Printmaking Now,” Brooklyn Museum of Art, Brooklyn, NY

"Curator's Choice: A Personal Look at Prints," Detroit Institute of Arts, Detroit, MI

"Summer in the City," John Berggruen Gallery, San Francisco, CA

"Bugs," Pace Prints, New York, NY

"Underfoot," Associacao Alumni, Sao Paulo, Brazil, to travel

"Kinds of Drawing," Herter Art Gallery, University of Massachusetts, Amherst, Massachusetts. Curated by Trevor Richardson (catalogue)

"Summer Group Exhibition," David Beitzel Gallery, New York, NY 
"High Art: Art of the Bank of America Tower," Bank of American Gallery, Seattle, WA

"Din Art 4," Museum fur Kommunikation, Frankfurt, Germany

"State of the Art 2001," International Biennial Watercolor Exhibition, Parkland College, Champaign, IL

"Luck of the Drawn,” Geoffrey Young Gallery, Great Barrington, MA

“Celebrating Women’s Art--Benefiting Women's Health: In honor of the Lynne Cohen Foundation for Ovarian Cancer Research,” Bobbie Greenfield Gallery, Santa Monica, CA

“Picturing the Modern Amazon,” The New Museum, New York, New York. Curated by Judith Stein, Laurie Fierstein and Joanna Frueh. Catalogue co-published by Rizzoli

“1001 Nights,” Landesmuseum, Linz, Austria (catalogue)

"Contemporary Narrative in American Prints,” Whitney Museum, Champion Branch, Greenwich, Connecticut

“Mapping Cities,” Boston University Art Gallery, Boston, MA, (illustrated catalogue)

"Drawing and Photographs," Matthew Marks Gallery, New York, NY

"The Likeness of Being: Self Portraits by Contemporary Women Artists,” Curated by Judith Stein, DC Moore Gallery, New York, New York

“The End: An Independent Vision of the History of Contemporary Art,” Exit Art, New York, New York

"Reconstructions: The Imprint of Nature/The Impact of Science,” Sidney Mishkin Gallery, Baruch College, New York, New York

"Selections from the Permanent Collection and Loans from Private Collections," Portland Art Museum, Portland, Oregon

“UTEP Millennium Printmaking Invitational,” Fox Fine Arts Center, University of Texas at El Paso, El Paso, Texas

"New Prints," David Adamson Gallery, Washington, DC

"Lasting Impressions," Portland Museum of Art, Portland, ME (catalogue)

"The Broad Spectrum: Color on Paper, Past and Present," The Art Institute of Chicago, Chicago, Illinois

Summer Group Exhibition, David Beitzel Gallery, New York, New York

“The Body as Question,” Speed Museum, Louisville, Kentucky, curated by Alice Stites (brochure)

"A Sense of Risk," Selections from the Shiffler Foundation, Miami University, Oxford, $\mathrm{OH}$

"Faster Than a Speeding Bullet: Superheroes in Contemporary Art," Cleveland Center for Contemporary Art, Cleveland, Ohio

Gallery Artists, Zolla Lieberman Gallery, Chicago, Illinois

"Fabled Impressions," Georgia Museum of Art, Athens, Georgia

"Women in Print," Jim Kempner Fine Art, New York, New York

"Elliot Green, Jane Hammond, David True, Trevor Winkfield," Tibor de Nagy Gallery, New York, New York

"Domestic Pleasures," Galerie Lelong, New York, New York

"Portraits," Jim Kempner Fine Art, New York, New York

"The New Museum Annual Benefit Exhibition," The New Museum, New York, New York

"Calendar 2000 Project," Center for Curatorial Studies, Bard College, Annondale-on-Hudson, New York

"Die Kunst der Linie" (The Artistic Possibilities of the Line), Landesgalerie Oberosterreich, Linz, Austria

"Secret Victorians," Curated by Ingrid Shaffner and Melissa Feldman, Firstsite, the Minories Art Gallery, Colchester, England; Arnolfini, Bristol, England; Ikon Gallery, Birmingham, England; Middlesborough Art Gallery, Middlesborough, England; The Armand Hammer Museum of Art, UCLA, Los Angeles, California; The Fabric Workshop, Philadelphia, PA (catalogue)

"Prints in the '90's from ULAE," Marlborough Chelsea, New York, New York; Fay Gold Gallery, Atlanta, Georgia; City Arts Center, Oklahoma City, Oklahoma; Locus Gallery, St. Louis, Missouri; James Kelly Contemporary, Santa Fe, New Mexico

"Artists on Line for ACOR," Curated by Elizabeth Murray and Richard Serra, Gagosian Gallery, New York, New York 
"Preview," Byron Cohen, Kansas City, Missouri

"Knowing Children," Curated by Anne Higonnet, David Beitzel Gallery, New York, New York

"Preserving the Past, Securing the Future," National Museum of Women in the Arts, Washington, DC

"Masters of the Masters," Curated by David Shirey, Butler Institute of American Art, Youngstown, Ohio (catalogue)

"Paper + Works on Dieu Donné Paper," Curated by Jaqueline Brody, The Gallery at Dieu Donné Papermill, New York, New York

"A Sustaining Passion: The Tsagaris/Hillberry Collection," Curated by Donald B. Doe, Ph.D and Lesley Wright, Ph.D, Cedar Rapids Museum of Art, Cedar Rapids, Iowa, Jan. 17-March 22, Dubuque Museum of Art, Dubuque, Iowa, April 13-June 28

1997 "New Work By Gallery Artists," Lemberg Gallery, Birmingham, Michigan

"Livres d'Artistes," Espace Cultural de Tingeux, Tingeux, France

"Michael Banicki, Jane Hammond, Tim Rollins + KOS," Gahlberg Gallery, College of Du Page, Glen Ellen, Illinois (brochure)

"ULAE: A Print Survey," Greg Kucera Gallery, Seattle, Washington

"Proof Positive: 40 Years of Contemporary American Printmaking at ULAE 1957-1997," Curated by Jack Cowart and Sue Scott, organized by the Corcoran Gallery of Art, Washington D.C., traveling to the University of Colorado, Colorado Armand Hammer Cultural Center at UCLA; Sezon Museum of Art, Tokyo, Japan (catalogue with illustration)

"New York," F15 Galleri, Oslo, Norway (catalogue with illustration)

"Collector's Choice," Orlando Museum of Art, Orlando, Florida (brochure with illustration)

1996 "Making Time," Kitteridge Gallery, University of Puget Sound, Tacoma, Washington

"The Changing Image," Curated by Anthony Iannacci, Gian Ferrari Arte Contemporanea, Milan, Italy (catalogue with illustration)

"Talk Back! A Forum for Critical Discourse," http://talkback.lehman.cuny.edu/tb

"100 Years of Collecting," Cornell Fine Arts Museum, Rollins College, Winter Park, Florida

“Contemporary Floral,” Steven Scott Gallery, Baltimore, Maryland

1995 "Recent Print Exhibitions," Museum of Modern Art (Curated by Riva Castleman)

"Insight," David Beitzel Galllery, New York, New York

Summer Group Show, Luhring Augustine, New York, New York

"This End Up: Selections from the Robert J. Shiffler Collection," organized by The Wyoming Art Museum and the Robert J. Shiffler Collection, University of Wyoming Art Museum, Laranue, Wyoming, traveling to The South Dakota Art Museum, Brooking, South Dakota; The Arvada Center of the Arts \& Humanities, Arvada, Colorado; The Cleveland Center for Contemporary Art, Cleveland, OH (1995-1997)

Group Painting Show, Galleri K, Oslo, Norway

"Playtime: Artists and Toys," Whitney Museum of Art at Champion,Stamford, Connecticut "Ten Young American Artists," Wetterling-Teo Gallery, Singapore

"Anxiety and the Irrational: Selections from the Permanent Collection," Whitney Museum of American Art, New York, New York

"Prints to Benefit the Foundation for Contemporary Performance Arts," Brooke Alexander Gallery, New York, New York

"The Magic Magic Book," The Whitney Museum of American Art, New York, New York "Reinventing the Emblem," Yale University Gallery, New Haven, Connecticut (catalogue)

"Large and Small: Prints from Universal Limited Art Editions," The Art Institute of Chicago, Chicago, Illinois

"Sex," Greg Kucera Gallery, Seattle, Washington

"Selections from the Collection: Recent Print Acquisitions," The Whitney Museum of American Art, New York, New York

"A Garden," Barbara Krakow Gallery, Boston, Mass.

"Who Chooses Who," New Museum of Contemporary Art, New York, New York 
"Not for the First Time," Richard F. Brush Gallery, St. Lawrence University, Canton, New York

"Night Visions and Other Obsessions," Marguerite Oestreicher Fine Arts, New Orleans, Louisiana

"Drawings for Lacanian Ink," Thread Waxing Space, New York, New York (catalogue)

"ULAE: New Editions" Brooke Alexander Gallery, New York, New York and Bobbie Greenfield Gallery, Venice, California

"Living with Art: The Saul and Ellyn Dennison Collection" The Morris Museum, Morristown, New Jersey (catalogue with illustration)

"Scratching the Surface" Curated by Stuart Anthony, Colgate University, Hamilton, New York

"New York Works on Paper" Geoffery Young Gallery, Great Barrington, Mass.

"Regarding Masculinity" Arthur Roger Gallery, New Orleans, Louisana

"Figure as Fiction" Curated by Elaine King, The Cincinnati Center for Contemporary Art

"Benefit for the Foundation for Contemporary Performance Art" Leo Castelli Gallery, New York, New York

"I, the Enunciator," Curated by Christian Leigh, The Thread Waxing Space, New York, New York (catalogue)

"The Fine Art of Patronage," Cranbrook Academy of Art Museum, Bloomfield Hills, Michigan

"Hypnosis," The Maryland Institute College of Art, Baltimore, Maryland

"Fear of Painting," Curated by Dan Cameron, Arthur Roger Gallery, New York, NY (brochure)

"Painting Culture," University of California at Irvine, Irvine, California

"Group Exhibition," John Berggruen Gallery, San Francisco, California

"Landscape as Stage," Curated by Rafael Rubinstein, Locks Gallery, Philadelphia, Pennsylvania (brochure with illustration)

"Hair," Curated by Alison Ferris, the John Michael Kohler Arts Center, Sheboygan, Wisconsin (catalogue)

Collectif Generation, Le Peintre, l'ecrivain et le livre, 1988-1992, Low Rotunda Memorial Library, Columbia University, New York, New York

"Jane Hammond, Valerie Parks, Archie Rand," Feigenson-Preston Gallery, Birmingham, Michigan

"Selections 1991: Recent Acquisitions of the Honolulu Advertiser Collection," The Contemporary Museum, Honolulu, Hawaii

"Gallery Selections," Feigenson Preston Gallery, Birmingham, Michigan

"Painted Word/Written Image," Greg Kucera Gallery, Seattle, Washington

"Four Painters," Nichido Gallery, Tokyo, Japan, Nichido Gallery, Nagoya, Japan (catalogue)

"Drawn in the Nineties," Curated by Joshua Smith for Independent Curators International, New York, traveling from June 1991-May 1994 to Katonah Art Museum, Katonah, New York. Fine Arts Gallery, Indiana University, Bloomington; Illingworth Kerr Gallery, Calgary, Alberta, Canada; Huntsville Museum of Art, Huntsville, Alabama (catalogue)

"43rd Annual Academy-Institute Purchase Exhibition," American Institute of Arts and Letters, New York, New York

"Painting Culture," fiction/nonfiction, New York, New York

"Livres d'Artists of Collectif Genération," Center for Book Arts and the French Cultural Services, New York, New York (catalogue)

"Marking the Decades: 1960-1990," Baltimore, Museum of Art, Baltimore, Maryland

"Group Exhibition - Drawings," Charles Cowles Gallery, New York, New York

"New U.L.A.E.," Pence Gallery, Santa Monica, California

"Words \& \#s," Museum of Contemporary Art, Wright State University, Dayton, Ohio (catalogue) 
"Drawing Conclusions," Molica guid Arte, New York, New York (catalogue with illustrations)

"Europa / America," Molica guid Arte, New York, New York

"Abstract Information: First Impressions, Last Resorts -- Printmaking at the End of the Century," Charles Plohn Gallery Sacred Heart University, Fairfield, CT, Bard College (catalogue with illustration), To Travel

"Gallery Artists," fiction / nonfiction, New York, New York

"Presswork: The Art of Women Printmakers," The National Museum of Women in the Arts, Washington, DC (catalogue with illustrations) To Travel: Atlanta College of Art; University Art Museum, University of Minnesota, Minneapolis; Elvehjem Museum of Art, University of Wisconsin, Madison; The Butler Institute of American Art, Youngstown, Ohio; Federal Reserve Bank Fine Arts Gallery, Kansas City, Missouri; Edwin A. Ulrich Museum of Art, Wichita State University, Wichita, Kansas; Portsmouth Museums, Portsmouth Community Arts Center, Portsmouth, Virginia; Spiva Art Center, Joplin, Missouri

"Benefit Exhibition: 14th Anniversary," The New Museum of Contemporary Art, New York

"The ICI 15th Anniversary Print Portfolio," Castelli Graphics, New York (To Travel: Pace Gallery, New York; Brook Alexander, New York; Myers Bloom Gallery, Los Angeles), (catalogue)

"Eye for Art II," Detroit Institute of Arts, Detroit, Michigan

"Cross Sections - Contemporary Art Collections in Detroit," Meadowbrook Art Gallery, Oakland University, Rochester, Michigan

"Barrett, Hammond, Salo, Wesley," Fiction/Non-Fiction, New York, New York

"Black and White," Nina Freudenheim Gallery, Buffalo, New York

"Retakes -- Prints and Drawings by 6 Canadian and 6 American Artists," Extension Gallery, Toronto, Ontario, Canada

"Word as Image: American Art 1960-1990," (Catalogue) The Milwaukee Art Museum, The Oklahoma City Art Museum and the Contemporary Arts Museum, Houston.

"42nd Annual Academy - Institute Purchase Exhibition," American Academy and Institute of Arts and Letters, New York, New York

"The Unique Print," Museum of Fine Arts, Boston, Massachusetts (Catalogue)

"11th British International Print Biennale," Bradford Art Galleries and Museums, Bradford, England (Catalogue) (to travel)

"La Bibliothèque Imagineé de Collectif Génération, Victoria and Albert Museum, London, England. (Brochure) Traveling to: Musée de Graveline, Graveline, France

"Sixth Sense," Pence Gallery, Santa Monica, California.

"Out of Abstraction," Islip Art Museum, Islip, New York

"Intimate Inventions/Gestural Abstractions," Madison Art Center, Madison, Wisconsin

"Waterworks," Universal Limited Art Editions, New York, New York (Catalogue)

"Gallery Selections," Fiction/Non-Fiction, New York, New York

"Faces," Marc Richards Gallery, Los Angeles, California

"Works on Paper," Shea and Beker Gallery, New York, New York

"Gallery Selections" Feigenson-Preston Gallery, Birmingham, Michigan

"The Fifth Essence," Gracie Mansion Gallery, New York, New York

"A Selection of Selections," Parsons School of Design, New York, New York

"Selections from The Laila and Thurston Twigg-Smith Collection," The Contemporary Museum, Honolulu, Hawaii

25th National Print Exhibition, the Brooklyn Museum, Brooklyn, New York (Catalogue)

"Visions of the Volcano," East Hawaii Cultural Center, Hilo, The Contemporary Museum, Honolulu, Hawaii, Stones Gallery, Kuai, Hawaii

"New Work," Feigenson-Preston Gallery, Birmingham, Michigan

"Ten Gallery Artists," Nina Freudenheim Gallery, Buffalo, New York

Summer Group Exhibition, Shea \& Beker, New York, New York

Invitational with Gallery Artists, Fiction/Non-Fiction, Gallery, New York, New York

Summer Group Exhibition, Ledis Flam Gallery, New York, New York

Summer Group Exhibition, Dolan/Maxwell Gallery, New York, New York 
"Invitational," Feigenson/Preston Gallery, Birmingham, Michigan

Summer Invitational, Works on Paper, Dolan/Maxwell Gallery, Philadelphia, Pennsylvania

"Small Paintings," Nina Freudenheim Gallery, Buffalo, New York

"Prints and Trial Proofs," Simon James Gallery, Berkeley, California

"Earth Remembered," Curated by Richard Mock, New York, New York

"Drawing and Related Prints," Castelli Graphics, New York, New York

100 Women's Drawings, Long Island University, C.W. Post Campus (Book), Blum-Helman Gallery, New York New York (to travel)

1988 "The New Generation," Elaine Benson Gallery, Bridgehampton, New York (Catalogue)

"Underknown in New York II," Hunter College, New York, New York

1987 "Painters Make Prints" (Catalogue), The Maryland Institute, College of Art, Baltimore, Md., Essex Community College, Essex, Md., Hood College, Frederick, Md., Frostburg State University, Frostburg, Md.

"Pastel Anthology II," Grace Borgenicht Gallery, New York, New York

Invitational Exhibition, Stux Gallery, New York, New York

"Paper," Dalsheimer Gallery, Baltimore, Maryland

1986 Small-Scale Abstraction, Grace Borgenicht Gallery, New York, New York

"Inaugural Exhibition," Cavin-Morris, New York, New York

SELECTED AWARDS:

2000

The Joan Mitchell Foundation Grant Award

1992

Artist-in-Residence, Skowhegan School of Painting and Sculpture, Skowhegan, Maine

1989

Louis Comfort Tiffany Award

New York State Council on the Arts Visual Artists Sponsored Work Award

National Endowment for the Arts Individual Fellowship in Painting

New York Foundation for the Arts Grant in Painting

$1987 \quad$ Art Matters, Inc.

"Painters as Printmakers," NEA grant (through the Maryland Institute) in Printmaking

1986 Mellon Grant, The Maryland Institute

1985 Ludwig Vogelstein Foundation Grant in Painting

Trustees Award for Excellence in Teaching Maryland Institute College of Art

1985

Summer Fellowship to Yaddo Artists' Colony, Saratoga Springs, New York

\section{SELECTED BIBLIOGRAPHY}

2011 Princenthal, Nancy, “Jane Hammond at Lelong,” Art in America, November, pp. 173-174, (illustration)

"It is Almost That: A Collection of Image+Text by Women Artists and Writers," Edited by Lisa Pearson, Published by Siglio

Mobilo, Albert, “Houdini: Art and Magic,” Bookforum, February/March, p.43 (illustration)

2010 MacAdam, Barbara A. “Jane Hammond at Pace Prints,” ARTnews, Summer, pp. 126-127, (illustration)

Dillon, Pamela, "Wright State Exhibit Delves into Art of Printmaking," Dayton Daily News, April 18, page D8, (illustration) 

Women in the Arts, Fall 2009, pp. 13-15 (illustrations)

Potter, Amanda, "Collecting Leaves, Assembling Memory: Jane Hammond's Fallen and the Function of War Memorials,” Archives of American Art Journal, Volume 47, Numbers 34, Fall 2008, pp. 66-77, (illustrations)

Hall, Emily, “Jane Hammond: Galerie Lelong,” Artforum, December, pp. 302-303, (illustration)

Wallach, Amei, “Jane Hammond’s Recombinant DNA,” Aperture, Vol. 191, Summer, pp. 50-55, (illustration)

Hirsch, Faye, “In Memoriam,” Art in America, April, pp. 132-133, 178, (illustration)

Fenchel, Luke Z., "Collecting Consciousness," The Ithaca Journal, March 20, Ticket Section, pp. 1, 8-9, (illustration)

Pickowicz, Natasha Li, “Lost and Found,” The Ithaca Times, March 12, pp.13, 17, (illustration)

Cordieiro, Will, “Transformational Grammars: 'Jane Hammnd: Paper Work,' “ The Cornell Daily Sun, February 8, p. E7, (illustration)

Aloi, Daniel, “Art as Language,” Cornell Chronicle, January 25, p. 16, (illustration)

Klaes, Larry, “Artist Creates 'Fictions from Facts' “

Goddard, Dan R, “Artist’s Collages Turn Photos Into Fiction,” San Antonio Express-News, September 26, p. G1

Lynch, Lisa Amato, “Jane Hammond: Paper Work,” Art New England, April/May, p. 31, (illustration)

Lippens, Nate, "Butterflies and Battlefields Share the Message in Jane Hammond's 'Souls', The Seattle Post-Intelligencer, February 9, p. 28

Cotter, Holland, "What F Word?” The New York Times, March 9, p. E24

Line, Elizabeth, “Passionate Attitudes,” PHOTOGRAPHY Quarterly, \#94, Vol. 23 p. 35-36 (illustration)

2006 Brune, Adrian, “Fresh Impressions,” The Hartford Courant, Hartford, CT, December 28, p. D1

Kley, Elizabeth, “Imagined Worlds: Willful Invention and the Printed Image 1470-2005,” ArtNews, April, p. 148

Molina, Angela, “Nous Mons,” El Pais, Barcelona, Spain, February 23, p. 49

Bufill, Juan, “Jane Hammond Expone sus Puzzles-Ficcion,” La Vanguardia, Barcelona, Spain, February 18 (illustration)

“Hammond is Artist in Residence,” West Hawaii Today, February 17, p. 7C (illustration)

Glueck, Grace, “Images of the Great Beyond, No Reality Check Required,” The New York Times, November 26, p. B11

Heartney, Eleanor, “Jane Hammond at Galerie Lelong,” Art in America, September, pp. 150-151 (illustration)

“Jane Hammond,” The New Yorker, April 18, 2005, p. 32

Fels, Sophie, “Jane Hammond, Galerie Lelong” Time Out New York, April 28- May 4, p.74 (illustration)

“Collaboration/Collage,” Indiana Review, Volume 27, Number 1, (Summer 2005), p.146-147, (illustrations)

Bembnister, Theresa, “Jane Hammond,” The Kansas City Star, September 15, p. 31 (illustrations)

2004 Glueck, Grace, “With Artists Among Alumni, A School Can Be a Collector,” The New York Times, July 26, p. E30

Richards, Judith Olch, Editor, Inside the Studio: Two Decades of Talks with Artists in New York, Independent Curators International, New York, pp.114-117 (illustrations)

Betti, Claudia and Sale, Teel, Drawing, A Contemporary Approach, Fifth Edition, Thomson/Wadsworth Learning, pp. 286-287, 308, 318, 341 (illustrations)

Schaffner, Ingrid, “Hula Dancer, Meet Mahtma Gandi,” Mount Holyoke Alumnae Quarterly, Spring issue, pp. 18-21 (illustrations)

Rubinstein, Raphael, En Quete de Miracle, Editions Greges, Montpellier, France pp. 61-62

“New Prints Review,” Art on Paper, November/December, p. 63 (illustration)

Lulaki, Susi and Berman, Laura, “The Rules of the Game,” Review, (Kansas City), April, pp. 44-47 (illustrations) 
Hackett, Regina, “Jane Hammond at the Greg Kucera Gallery,” Seattle Post-Intelliegencer, January 23, p. (illustration)

Liorca, Pablo, The Termites and the Elephant, Exhibition catalogue for "Arte Termita Contra Elefante Blanco” p. 69 (illustration), p 202, ICO Foundation, Madrid, Spain

Fugate, Marty, "The Elephants in the Room," The Longboat Observer, December 16, p. 5C Gonzalez, Allyson, “Space Crunch,” Weekly Planet (Sarasota, FL), Nov. 17-23, p. 41

Genocchio, Benjamin, “To Understand These Pictures, You May Need a Dictionary,” The New York Times, (CT), December 21, p. 13, (illustration)

Streitfeld, L.P., "Creating New Cosmologies at Westport Art Center,” The Advocate and Greenwich Time, December 14. pp. D3-D4

Melby, Julie, Splendid Pages: The Molly and Walter Bareiss Collection of Modern Illustrated Books, Exhibition catalogue published by the Toledo Musuem of Art, Toledo, $\mathrm{OH}$

Rubinstein, Raphael, “A Quiet Crisis,” Art in America, March, pp. 39-45

"Art A Century Apart," The Clarion-Ledger," (Jackson, MS), March 2, pp. 3F, 5F, (illustration) Rubinstein, Raphael and Hammond, Jane "On Collaboration," Artkrush, Issue 2, artkrush.com Cohen, Keri Guten, “Jane Hammond: Shanghai Costumes,” Detroit Free Press. May 18, (illustration) Chistopher, Andre, “Art History,” Tennis Week Magazine, May 6, Cover and p. 43 (illustration) Lance, Tony, "Poster Girl,” Tennis Magazine, June, p. 44 (illustration)

Lehody, Frank K., “The Model Daughter,” Roland Garros Magazine, pp. 56-60, (illustration)

Lehody, Frank K., “Le Meilleur d'Hammond,” Roland Garros’ Le Quotidien Officiel 2003, pp. 3839 (illustration)

Lehody, Frank K., “Jane Hammond en Sept Questions,” La Tribune de Roland Garros, Avril/Mai, pp. 1-2 (illustration)

Myers, Terry R., (jane hammond's) composition (notebooks) as (much more than) explanation, exhibition catalogue for Weatherspoon Art Museum, The University of North Carolina, Greensboro, North Carolina

Wallach, Amei, "To a Painter, Words are Worth a Thousand Pictures," The New York Times, October 13, Arts and Leisure, Section Two, pp. AR 1, AR 35 (illustrations)

American Visionaries: Selections from the Whitney Museum of Art, Whitney Museum of American Art, New York

Hirsch, Faye, “Working Proof: Jane Hammond and Raphael Rubinstein” Art on Paper, December, 2002, pp. 54-55 (illustrations)

Lovelace, Carey, "Jane Hammond at Galerie Lelong," Art in America, April, pp. 152 -153 (illustration)

Carrier, David, "Jane Hammond at the Cleveland Center for Contemporary Art," Artforum, March, p. 144 (illustration)

Princenthal, Nancy, Be Zany, Poised Harpists, Be Blue, Little Sparrows, Exhibition catalogue published by Dieu Donne Lab Grant Program, Dieu Donne Papermill, New York, NY

Lehman, David, "Jane Hammond," The Frances Dittmer Series on Contemporary Art, BOMB magazine, Fall 2002, pp.28-35 (illustration)

Rubenstein, Raphael, Back Stage: Secrets of Scene Painting, Exhibition catalogue published by The Whitney Museum of American Art at Philip Morris, New York, NY

Hirsch, Faye, "Paper Pulse: A Conversation with Jane Hammond," Art On Paper, March-April, Cover and pp. 64-69 (illustrations)

Newhall, Edith, "Set Pieces," New York Magazine, January 21-28, p. 95 (illustration)

Devine, John, "What's in a Name," Houston Press, October 31-November 6, p. 58 (illustration)

Johnson, Patricia C, "Play on Words," Houston Chronicle, September 28, 2002, pp. 9-10D (illustration)

Perwaiz, Uruj, The Daily Cougar, October 2, p. 12 (illustration)

"Art of the Butterfly: Body Language 2002 by Jane Hammond," American Butterflies, Summer 2002, pp. 42-43, (illustration)

Morse, Marcia, "Archaeology of the Surreal," Honolulu Weekly, May 22-28, p. 9 (illustration)

Rizk, Mysoon, "Jane Hammond at the Cleveland Center for Contemporary Art," New Art Examiner, May-June, p. 91 (illustration)

Hammond, Jane, "In Her Own Words: Wonderful You," Women in the Arts, Fall 2002, pp.8-9 (illustration)

Uberquoi, M.C., "Jane Hammond," El Cultural, Barcelona, Spain, December 5-11. 
2001 Digital: Printmaking Now, Exhibition catalogue, Brooklyn Museum of Art, Brooklyn, NY

Hirsch, Faye, "Working Proof,” Art on Paper, July-August, 2001, p. 62 (illustration)

Keri Guten Cohen, “Jane Hammond at Lemberg,” Detroit Free Press, February 25, 2001, page 7G

Joy Hakanson Colby, “Jane Hammond Puts Her Energy on Paper,” The Detroit News, March 2, 2001

2000 Frueh, Joanna, Fierstein, Laurie, and Stein, Judith, Picturing the Modern Amazon, Rizzoli and New Museum Books, New York.

Zimmer, William, “A Return to the Stories that Viewers May Have Been Missing,” The New York Times, Sunday, January 16, p. 18 (illustration.)

Die Kunst der Linie, Exhibition Catalogue, Landesmuseum, Linz, Austria

Yovens, Rachel, “The Likeness of Being: Contemporary Self-Portraits by 60 Women,” New York Arts, Vol. 5, no. 1, pp 49-52 and cover.

Cembalest, Robin, “The Woman in the Mirror,” Elle, Jan. 2000, p. 34 (illustration.)

Rubinstein, Raphael, “Ashbery in Dargerland,” Art in America, Feb. 2000, pp 37-39.

Hirsch, Faye, "Working Proof,” Art on Paper, March-April 2000, p. 64 (illustration)

1999 Lustfeldt, Heather, “Jane Hammond at Cohen,” Review, Dec. 1999, Vol. 2, \#2, p. 21.

Molina, Angela, "Jane Hammond, en el Cementerio de Elefantes," ABC Newspaper, November 15,

Oliver, Conxita, “El Velar I el Desvelar de Jane Hammond,” Avui Newspaper, Culture Magazine supplement, Nov. 18, 1999, p. 19.

Johnson, Ken, “Printmaking as a Magical Collaboration,” The New York Times, July 30, 1999, p. B35.

Johnson, Ken, “Art Guide,” The New York Times, July 16, 1999, p. B38.

Harrison, Helen A., "Updating and Adapting Traditions, of a Country or a Medium," The New York Times, Sunday, February 14, p. 23 (illustration.)

Cohen, Keri Guten, "Jane Hammond," Detroit Free Press, Sunday, May 2, p. 2 E.

Salvaggio, Denise, "Living With Art," Orlando, April, pp. 50-54.

1998 A Sustaining Passion: The Tsagaris/Hillberry Collection, Exhibition Catalogue published by Cedar Rapids Museum of Art.

Vincent, Steven, "Silicon Gallery," Art \& Auction, January, pp. 76-79, 114-115.

Troy, Maria, "Greenville Rocks," The New Art Examiner, March, pp. 32-37 (illustration.)

Johnson, Ken, "Jane Hammond," The New York Times Art Guide, p. E36, March 13.

Mitchell, Ben, "Jane Hammond at Greg Kucera," Artweek, January.

Corbett, William, "Queen Jane Approximately," Modern Painters, Summer, pp. 88-89.

Brody, Jaqueline, "Paper," Brochure essay for exhibition at Dieu Donné Press and Paper.

Thorson, Alice, "Cohen's 'Preview' United Abstract Talents," The Kansas City Star, July 24, p. 11.

Osman, Jana; Spahr, Juliana; Zweig, Janet, "Different Languages," Chain, Issue 5, Small Press

Distribution, Berkeley, California, pp. 96-98 (illustration.)

Oksenhorn, Stewart, "Creating Art Out of Pandemonium," Aspen Times Weekly, June 27-28, pp. 1B, 9B10B.

Cedrins, Inara, "Knowing Children," Cover, vol. 12, \#4, p. 51 (illustrtion.)

1997 ArtNews Special, January, p. 50.

New York Magazine, April, p. 145.

Levin, Kim, "Jane Hammond," The Village Voice, April 16-22, p. 12.

Corbett, William, "Highlights: New York," Artsmedia, June, p. 35.

Rubinstein, Raphael, "Jane Hammond at Luhring Augustine," Art in America, September, pp. 106.

Schmerler, Sarah, "Jane Hammond," ArtNews, September, p. 130.

Howard, Malcolm, "Universal Images," The Colorado Springs Independent, pp. 9-14.

Betti, Claudia and Sale, Teel, Drawing, A Contemporary Approach, Fourth Edition, Harcourt Brace College Publishers, pp. 293-294 (illustration.)

Schwabsky, Barry, "New York," catalogue essay for Gallery F-15, Moss, Norway.

Sandberg, Lotte, " New York pa Jeloy," Aften Polten, Octer 12, p. 25 (illustration.)

Flor, Harald, "Vold og Tyggis," Dagbladet, October 1.

Jortveit, Anne Karin, "Chanel, pistalskudd-og liuslinjer," Klassekampen, October 4, p. 33

(illustration.) 
Olsen, Ragnhild, "Med (tyggis) under stolen," Moss Avis, September 12, pp. 12-13 (illustration.)

Cameron, Dan, "Glocal Warming," ArtForum, December, p. 20.

Hackett, Regina, "Hammond's Savvy Surrealism Makes Conscious Use of the Unconscious," Seattle Post Intelligencier, November 21, p. 21.

Klawans, Stuart, "Museums," The Daily News, April 26.

1996 Smith, Robert, "A neo-Surrealist Show with a Revisionist Agenda," The New York Times, January 12, p. C23.

Duncan, Michael, "Report from Los Angeles," Art in America

, January, p. 39.

Holg, Garrett, Review of Zolla/Lieberman, Art News, February, p. 141, Framework, Vol. 7 Issue 3, p. 52.

Princenthal, Nancy, Now You See It, You Don't: The Magic Magic Book, Parkett 47, pp.184-187

Suto, Wilma, "Een oor met ogen en een open boek," De Volkskrant, February 9.

Lutticken, Sven, "De beeldbank van Hammond, " March 1.

Warlow, Emma, "Desireable Deco," Apartment Living, April/May, p. 47 (cover image.)

Colby, Joy Hakansan, "Anything Goes...Together in Hammond's Art," The Detroit News, Thursday, April 4, p. $1 \mathrm{~F}$.

Provenzano, Frank, "Layered Lyricism," Metrotimes, May 15-21, p. 20. Campbell, Shane, "Jane Hammond," The New Art Examiner, September.

Bee, Susan and Schor, Mira, "Jane Hammond," New Observations, \#113, Winter, cover, pp. 8-9.

Yeo, Ricky, "Looking Good," IQ Magazine (Singapore,) cover, pp. 28-32.

1995 Pagel, David, "Entering a Psychic World of Stimulating Hyperactivity," Los Angeles Times, January 19, 1995, F.8.

McGee, Celia, "Book Tricks from Ricky Jay and the Whitney," The New York Observer, p. 24.

Frank, Peter, "Art Picks of the Week: Dominique Blain, Jane Hammond, Subtle Differences," LA Weekly, February 3-9, 1995.

Field, Richard, "Contemporary Emblems," Reinventing the Emblem, Yale University Art Gallery, New Haven, CT.

Diehl, Carol, "Jane Hammond--Jose Freire," ArtNews, February, p. 126.

Stein, Judith, "The Word Made Image," Art in America, May, pp. 98-101.

"The Printroom of the Yale University Art Gallery," Print Collector's Newsletter, March-April 1995, p.14.

Scott, Sue, "Selective Visions," Art \& Antiques, November, pp. 92-95.

"1995 Acquisitions-The Hallmark Collection." (back cover.)

Cuperman, Pedro, "Sips and Slips," Point of Contact, Vol. 4, No. 2, Fall, pp. 73-80.

Zinnes, Harriet,"Jane Hammond," Art Papers, March and April, p. 57.

Hackett, Regina, "Sex Show at Greg Kucera Runs Controversial to Serene," Seattle Post Intelligencer, February 10.

1994 Smith, Roberta, "Jane Hammond at Jose Freire," The New York Times, November 4, 1994, p. C30.

Cottingham, Laura, "On the Precipice of Poetic Justice," Catalogue essay for the exhibition at Jose

Freire Fine Art, New York City, October.

Cameron, Dan, "Critical Edge: The Easel Way Out," Art \& Auction, December, pp. 66-69.

Staff, "Here Comes the Future: 25 Faces Facing Forward," Interview Magazine, October, p. 66.

Staff, "Self-Portrait by Jane Hammond," The New Yorker, October 31, 1994, p. 22.

Bishop, Philip, "Her Painting Are Meditations on Detail," The Orlando Sentinel, December 11, 1994.

1993 Kertess, Klaus, "See Jane Paint," April, essay for exhibition at Jose Freire Fine Art, New York, New York.

Findsen, Owen, "Exhibits for Art Museum's 1993-94 Season," Cincinnati Enquirer, June 23.

Hackett, Regina, "Review," Seattle Post-Intelligencer, April 16, p. _ (illustration.)

Ament, Doloris Tarzan, "New York Artist Makes Beautiful Impressions," The Seattle Times, April 8 (illustration.)

Johnson, Ken, "Jane Hammond at Jose Freire," Art in America, October, p. 126 (with illustration.)

Cameron, Dan, "What Goes Around," Art and Auction, October 1993, pp. 80-81. 
Cotter, Holland, "Review," The New York Times, April 23, 1993 p. C28.

Levin, Kim, "Voice Choice," The Village Voice, April 13, 1993.

The New Yorker, "Finite Universe," April 12, 1993, page 14.

Iannacci, Anthony, "Review," ARTFORUM, January, 1993, (illustration).

1992 Wasserman, Burton, "Exhibitions in Sight," Art Matters, February 1992, p. 3.

Cameron, Dan, "Don't Look Now," Frieze, Issue 3, pp. 4-8.

Drucker, Johanna, "Visual Pleasure: A Feminist Perspective," Meaning \#11, May 1992, pp. 3-11.

Hermanns, Ralph, "Pussellexicon för Konstnarer," Dagens Industri, Sweden, page 43, with illustrations.

Olofsson, Anders, "Jane Hammond," Material \#8, 1992, page 43.

Cameron, Dan, The Outlaw Academy," Art and Auction, April 1992 p. 96-98.

Williams, Gilda, "Review," Flash Art, December 1992, Italian Edition.

Dubin, Zan, "Painting Themselves Out of a Corner," Los Angeles Times, October 10, 1992 (photo).

Curtis, Cathy, "Women's Work: Rich, Shocking," Los Angeles Times, October 16, 1992.

Liberio, Lydia, "What If Andy Warhol and Roy Lichtenstein Had Been Women?" The Irvine World News, October 15, 1992, p. B17 (photo).

Myers, Terry R., "Fear Strikes Out," QW, October 4, 1992, pp. 38-39.

Ayerza, Josephina, "Interview with Jane Hammond," Lacanian Ink, \#6, pp. 68-75 (with illustrations).

1991 Evans, Steven, "Review of Painting Culture," NYO, November 10, p. 34.

Kozik, K.K., "Jane Hammond, fiction/non-fiction," Cover Magazine, October 1991.

Mahoney, Robert, New York reviews, Art \& Antiques, October 1991.

Kimmelman, Michael, "Painting Culture," The New York Times, November 1, 1991.

Hess, Elizabeth, "Death to the Masters," Village Voice, October 22, 1991.

Cyphers, Peggy, "New York in Review," Arts Magazine, September 1991, p. 7

Rosenberg, Barry A. and Carol Nathanson, "Words \& \#s," Museum of Contemporary Art, Wright State University, Dayton, Ohio, 1991 (illustrations).

Handy, Ellen, "Abstract Information -- First Impressions, Last Resorts: Printmaking at the End of the Century," Sacred Heart University, Fairfield, CT (with illustration).

Levin, Kim, "Voice Choices: Jane Hammond at fiction/nonfiction," The Village Voice, June 4, p. 115

Taylor, Fredrieke, "Alchemy," New Observations, number 84, New York, NY (with illustrations).

Colby, Joy, Detroit News, March 29, 1991, pp. 1C-2C.

Miro, Marcia, Detroit Free Press, March 31, 1991, page 4C.

Hixson, Kathryn, "Chicago in Review," Arts Magazine, January, p. 107 (with illustration).

1990 Creeley, Robert, "Never Lose Your Paper," catalogue essay, Universal Limited Art Editions, New York, NY.

Ackley, Clifford, "The Unique Print Today," catalogue essay, Museum of Fine Arts, Boston (with illustration).

Kiehl, David, "On American Printmaking," catalogue essay.

11th British International Print Biennale, Bradford Art Galleries and Museums, Bradford, England.

Bowman, Russel and Dean Sobel, "Word as Image: American Art 1960 to 1990," catalogue essay, Milwaukee Art Museum, Milwaukee, Wisconsin (with illustration).

Handy, Ellen, "The Pearls and the String, Jane Hammond's Associative Method," Arts Magazine, September, pp. 47 through 51 (with illustrations).

Ashbery, John, Catalog Essay, "Jane Hammond New Paintings," Wetterling Gallery, 1990.

McCracken, David, "Hammond Leaves Pictorial Story to Viewer," Chicago Tribune, Friday, November 16, 1990.

Barckett, Lynda, "Jane Hammond at the Zolla/Lieberman Gallery," Reader, Friday, November 23, 1990, p. 29.

Enders, Alexandra, "Family Portraits," Art \& Antiques, October, p. 67 (with illustration).

McGovern, Adam, "Summer Group Show: Prints and Works on Paper," Cover, September.

Harrison, Helen, A., "Blurring Artistic Distinctions," The New York Times, July 8.

Jensen, James, "Recent Paintings," catalogue essay for exhibition at the Honolulu Academy of Arts, Honolulu, Hawaii, May/June 1990. 
Myers, Terry, R., "New York Fax," Art Issues, May 1990, p. 34.

Hess, Elizabeth, "Fly on the Wall," The Village Voice, February 27, 1990, p. 84 (with illustration).

Atkins, Robert, "New This Week," Seven Days, February 28, 1990, p. 52.

Myers, Terry R., "Review," Flash Art, Summer 1990, p. 150 (with illustration).

Myers, Terry R., "Review," Art Today-Videotape, February, 1989.

Morse, Marcia, "Disparities the Eye Somehow Connects," The Sunday Star-Bulletin and Advertiser, June 17, 1990, Honolulu, Hawaii, page E10 (illustrations).

Walker, Barry, "Projects and Portfolios," catalogue essay for exhibition at the Brooklyn Museum Brooklyn, New York, October (with illustration).

Creeley, Robert, "Here," Catalog Essay, Exit Art, 1989 (with illustrations).

Myles, Eileen, "Review," Art in America, October, p. __ (with illustration).

Papadakis, Andrea, ed., New York, New Art, vol. 5, pp. 62-65 (England) (with illustration).

Miro, Marsha, "Review," Detroit Free Press, August 13, 1989, p. 6 G (with illustration).

Henry, Gerrit, "Reading Jane Hammond," The Print Collector's Newsletter, September-October, pp. 128-129 (with illustration).

Shestak, Mel, "New York," Contemporanea, September, p. 33.

Hirsh, David, "Summer Thrills for Humid Heat," The New York Native, July 24, p. 30.

Atkins, Robert, Arena (Spain), June, pp. 109-110 (with illustration).

Cirincone, Janine, "Review," Cover Magazine, April, p. 14.

Bass, Ruth, "Review," ARTnews, May, pp. 171-172 (with illustration).

Mahoney, Robert, "Review," Arts, Summer, p. 96 (with illustration).

Ôblêk, Spring 1989, 11 illustrations.

Van Wagner, Judy K. Collischan, Lines of Vision, Hudson Hills Press, NY, p. 69 (with illustration).

1987 Huntington, Richard, "Hammond Paintings Present a Challenge," The Buffalo News, December 9, p. 27.

Bass, Ruth, "New York, New York," ART-TALK, August/September, p. 58.

Dorsey, John, "Six Painters Try Their Heads at Printmaking," The Baltimore Sun, June 4, 1987, E1, 6 (with illustration). 